\title{
CONDITIONS OF TECHNICAL CREATIVITY AT VARIOUS STAGES OF EDUCATION
}

\author{
Henryk Noga \\ Barbara Garbarz-Glos \\ Krzysztof Pytel \\ Piotr Migo \\ Pedagogical University in Cracow, Poland
}

\begin{abstract}
Creativity develops, regardless of the age we are, it is never too late to find owns passion for creativity, which in my opinion is hidden somewhere in the depths of ourselves. Creativity involves the area of passion, with interesting way of spending time with the creating of unique objects, proper motivation and the desire to obtain gratifications and possibility to show created works. The study shows selected conditions of students technical creativity at different stages of education. The aim of the study was It was to analyse the determinants of creativity in the various stages of education in Poland. Research took place in junior high school. On the basis of research factors that create creativity are: knowledge, abilities and skills, the ability to develop their own individual interests, level of motivation.
\end{abstract}

Keywords: conditions, creativity, stages of education technical education.

\section{Introduction}

The word create derives from the Latin words creatus and creare which means: to produce, make and grow (Smidt, 2007). The meaning of these words is closely linked with the idea of creativity. There are many definitions of creativity, as there are many ideas that creativity derived. It is a concept that everyone can defined slightly differently.

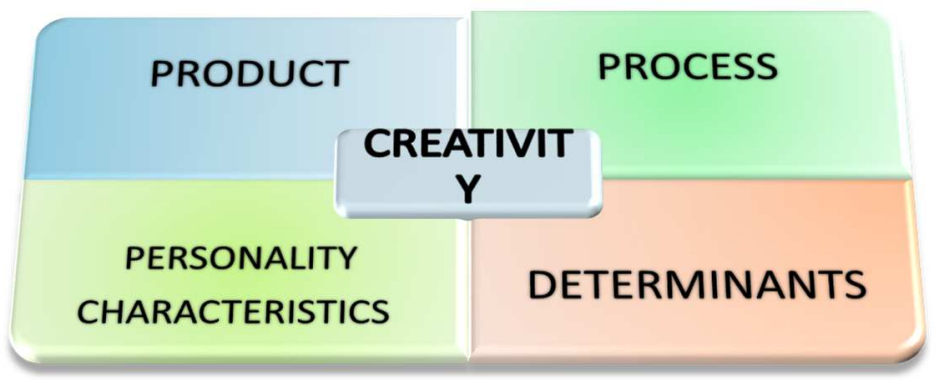

Figure 1 Four aspects of creativity (own compilation based on Smidt, 2007)

(C) Rēzeknes Tehnologiju akadèmija, 2017 http://dx.doi.org/10.17770/sie2017vol4.2278 
The world surrounding us, technological progress, constantly development of innovation led the creativity on a new level, as also in the educational process. creative thinking and activities and above all the development of creative abilities has been appreciated (Kołodziejski, 2009). At the moment ones creativity can be determined by each person who creates a new reality by technical projects, products of various types, creative thinking, cooperation in group in order to perform, develop creative thinking among team members. Active man who explores wants to develop knowledge and skills in many areas, but usually focuses on issues for him most interesting (Góralski, 1090; Ptak, 2012).

\section{Creativity in the educational practice}

In the book, Pedagogy of creativity, Christopher J. Smidt recognize rules used in the teaching of creativity as a certain standards which are designed to help teachers achieve the goals during class. Compliance with the rules will affect the operation of the teacher, his behavior during classes makes the classes are more interesting and reinforces the effect of education (Szmidt, 2007).

The principles of creative activities indication that at the beginning one must provide a variety of materials and a suitable place to perform activities. During performing tasks teachers should support children in activities associated with the demonstration of creative attitudes, should motivate them so they use different techniques, and carried out their fantasies and ideas. The child should feel appreciations, motivation, even if we introduce innovative solutions to the project and it does not bring the desired solutions. The teacher should also use different techniques (which stimulate the creative cognitive processes of the child), and indicate their use (Kubicka, 2005).

Teaching methods are defined by Christopher J. Schmidt as defined and deliberately used methods for stimulating, promoting and developing skills and creative thinking, as well as the disposal of emotional-motivational and as components of behavioral attitude of pupils creativity' (Szmidt, 2007; Haškova, 2015).

Methods used in teaching creativity aims to develop creative abilities of children and youth as well as adults, they are primarily associated with knowledge concerning the subject of creation. Among the methods for teaching creativity, major significance have methods associated with cognitive features, student's curiosity and use of divergent thinking (involving the ones creativity, solving open issues that shapes and improves the ingenuity of the student) analogs and metaphor (Szmidt, 2007). 


\section{Research Methodology}

The aim of the study was It was to analyze the determinants of creativity in the various stages of education in Poland. The research problem came down to the question: What are the determinants of technical creativity at different stages of technical education. An attempt was taken to investigate to determine these conditions and to analyze whether they differ depending on the stage of education. Creative person can better handle in everyday life, one can look for certain information to draw conclusions for the future from various events. I base this statement on the basis of my several years of professional experience. Students involved in any creative activity it easier to integrate, talk to each other, have more ideas and be more willing to help, eg. In the preparation of all kinds of events, decorations, etc. Wherever a group of people with a common passion will gather then we can feel calm and friendly atmosphere, this is the ideal area to rest, provided that we like and we like this type of creative work (Prauzner, 2014). Such activities help to pass the difficult moments of life related to eg. Illness, solitude, momentary lack of acceptance - in this way, a person can call for help, understanding, but as well creativity can be used for relax, pleasure, desire to show and demonstrate skills, especially which operates for a long time. Everyone wants to be appreciated, praised - what increases self-esteem as well, which I think is very important - build motivation for action (Depešová in, 2001).

In order to develop student's skills in various fields of art, one should take care of the creativity in broader concept, not just about developing the capacity out of certain field. It should also develop a motivation for creative activities. Problems related within research in this study were formulated in an attempt to answer the following questions:

1. What is "creativity" - an attempt to explain the concept of the subjects at different ages.

2. How to motivate students for creative work?

3. What techniques associated with handicrafts are known to studied at different stages of education - identification.

4. What activities (especially artistic) would be attractive to students (especially secondary school students' opinion, due to the possibility of conducting such workshops in schools)

5. When and how students can use their creative skills in everyday teaching practice

In studies associated with creativity it calls primarily attention to four aspects of the work of issues namely, the process (of the generation), the product, the creator (the contractor of the product - a product) and external factors which often cannot be influenced. Creativity involves much with motivation for intensifying action (Gumuła et al., 2014). Studies of creativity one can divided into three main 
streams of methodological approaches it could be distinguished approach psychometric, experimental and biographical. The test methods can be divided in another way, by the quantity (related to the purpose of the study and possible of developments) and qualitative (related with research tools) (Szmidt, 2007).

The research was carried out on the group of pupils attending Gymnasium in Complex School and Preschool in Bestwince and high school students in the Secondary School "Silesia" in Czechowice-Dziedzice. Were examined 62 people including 32 boys and 30 girls. The first group consisted selected person in the age 13 to 16 years, the second group consisted students studying in technical professions: technician of organization advertising and technician, in classes with pupils at age between $16-20$. Tested was also a small group of people associated with the school environment (including teachers, determined as adults) to understand their point of view on issues related with creativity (Pytel, 2012). This group represents only certain reference in relation to groups of junior high school students and high school. I wanted to know opinions of people around me, to the subject contained in the surveys and therefore the analysis of the answers given by those surveyed only in some cases. Then, could you (in my opinion) observed significant differences between the statements of adults and adolescents.

In conducting research were used an electronic surveys. During the available questionnaire, I received 62 questionnaires. In total, among the respondents were $48 \%$ of girls and $52 \%$ boys, including $24 \%$ of junior high school students, $64 \%$ high school pupils and $12 \%$ of people over the age of 20 .

The questionnaire was available on Google Drive. Link to a website was send to junior high school students by the teachers of technology and computer science, at my request, and I passed them to high school students and a few teachers. The questionnaire was made by using the "google form" (which is located in the options of the service of "Google Drive"), which is available on the www.google.pl, after earlier logging on to electronic mail associated with Gmail.

\section{Determinants of technical creativity according to research}

At the beginning respondents were asked What is "creativity and what subjects understand the concept of creativity". Selected answers to this question, taking into account the distinction between stages of education (junior high school, upper secondary school) and in addition adults. 


\begin{tabular}{|c|c|}
\hline & expanding their field of interest, the ability to create creative solutions \\
\hline & the ability or the features to create or invent a variety of new things \\
\hline & express themselves in a creative, intelligent way \\
\hline & the ability to to express oneself, being open to the world \\
\hline & ability to think and create by their own ideas \\
\hline & our ideas for something new, original \\
\hline \multirow[t]{3}{*}{ is } & a feature that possess people with exceptional talent, who are able to use it \\
\hline & creating something \\
\hline & a masterpiece and creativity \\
\hline
\end{tabular}

Figure 2 Answers given by students of Gymnasium

Creativity (based on the responses of students) is associated with expressing and showing themselves, resourcefulness, with the production of something great and original. It enables to develop ones interests and different types of skills, that lead to the creation of new works, shaping human creativity. Replies of secondary school students are similar to the answers of junior high school students, but more often appearing with the term of "creativity". For small part of the students, however, there was a problem with the explanation of the concept. In their responses appears resourcefulness, and most often repeated phrase "creating something." Some comments are very interesting, surprising and really creative. I placed those answers in the table below.

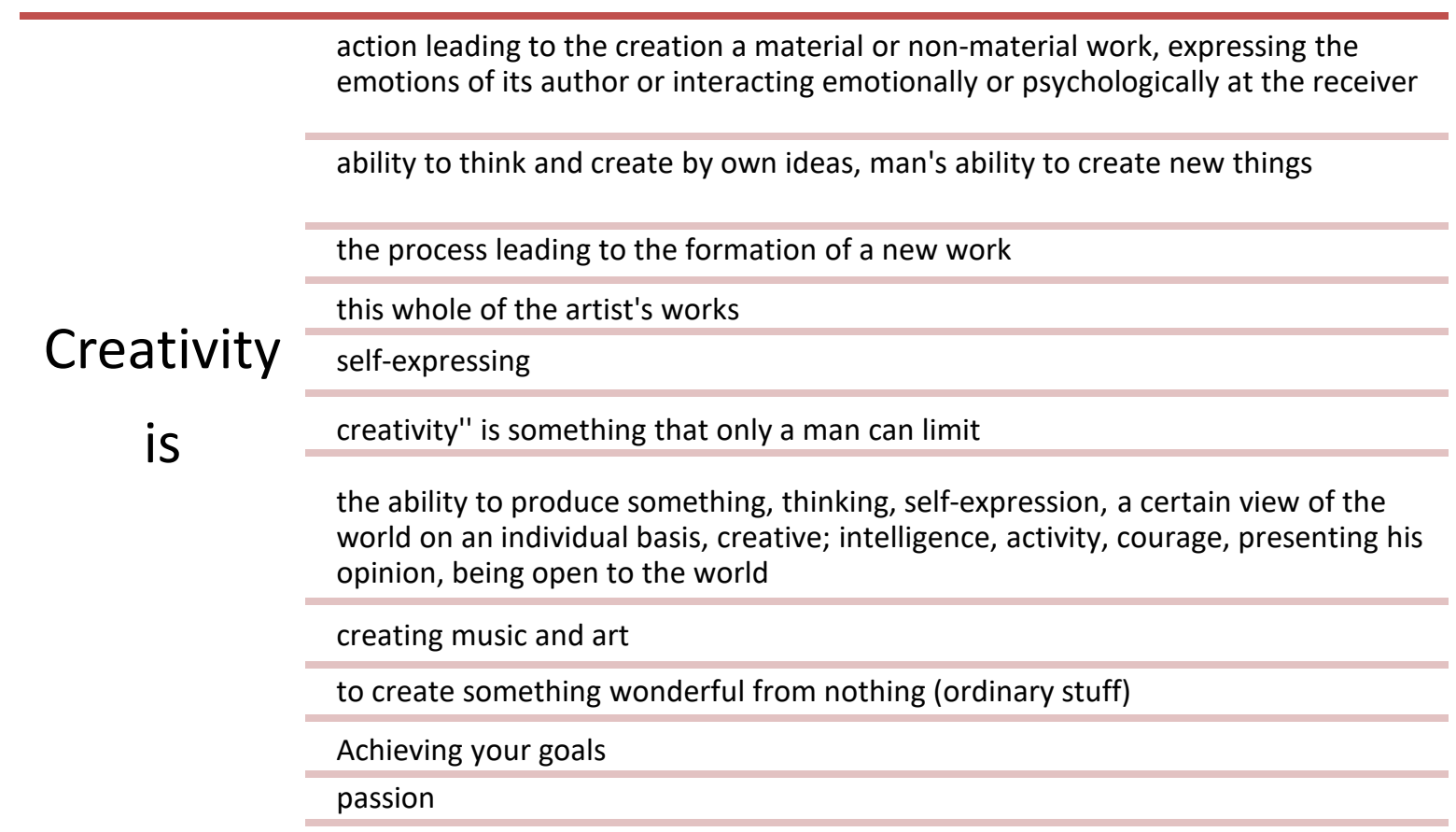

Figure 3 Answers given by students of Secondary School 
Henryk Noga, Barbara Garbarz-Glos, Krzysztof Pytel, Piotr Migo. Conditions of Technical Creativity at Various Stages of Education

Adults expressed themselves in a mature way, but their comments (in meaning) were similar to younger groups. It was confirmed by the complexity of the notion that "creativity" and the difficulty of its definition. Below I presented adults answers (see Fig. 4):

creation of art works, whole works created by the artist
the ability to produce something in a physical way or presenting their views
Creativity $\quad$ work created by someone, activity, creativity
is
handicraft paintings, sculpture....
ability to find new solutions.
passion, develop the capacity and new skills

Figure 4 Answers given by Adults

Among the available three answers: "yes," "no," "I do not know" respondents could select only one (in his opinion a right) answer. The values associated with this question are presented in the table below.

Table 1 Answers for the first question

\begin{tabular}{|c|c|c|c|}
\hline \multirow{2}{*}{} & \multicolumn{3}{|c|}{ Number of answers } \\
\cline { 2 - 4 } & Yes & Yo & Hard to say \\
\hline Gymnasium students & 54 & 0 & 46 \\
\hline $\begin{array}{c}\text { Secondary schools } \\
\text { studets }\end{array}$ & 60 & 2,5 & 37,5 \\
\hline adults & 57 & 14 & 29 \\
\hline
\end{tabular}

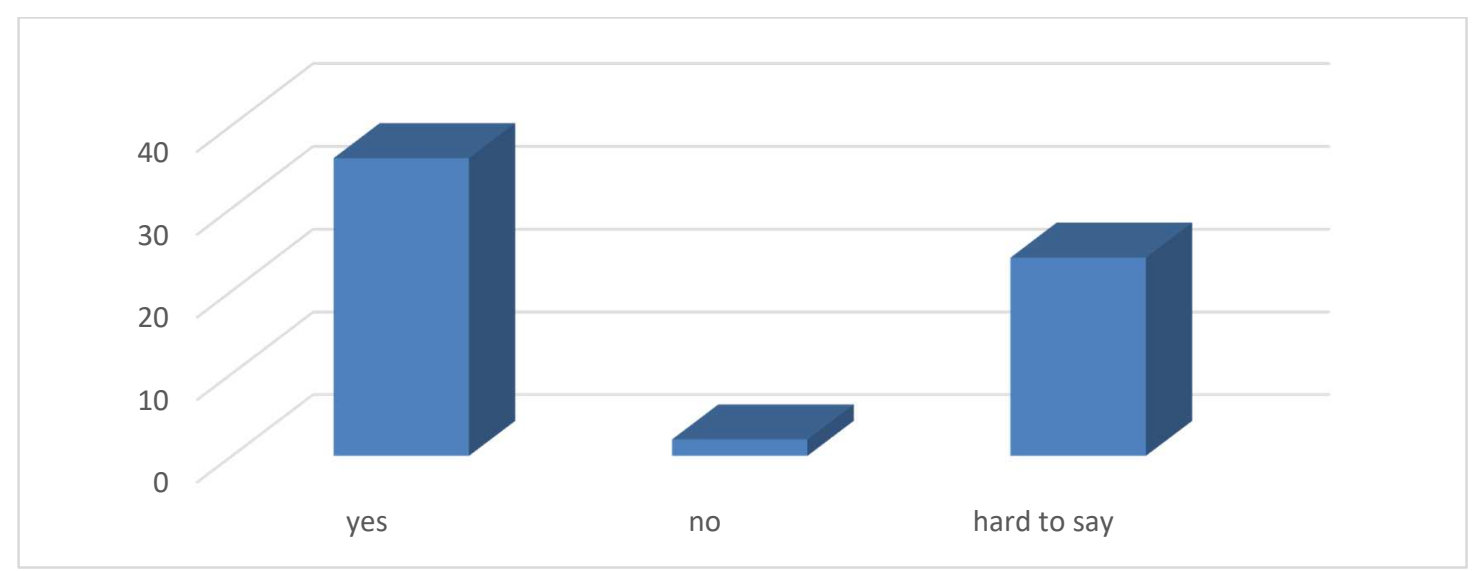

Figure 5 Total answers for question about being creative 
According to the survey, most respondents considered to be a creative person. Below is an analysis of the response to the next question.

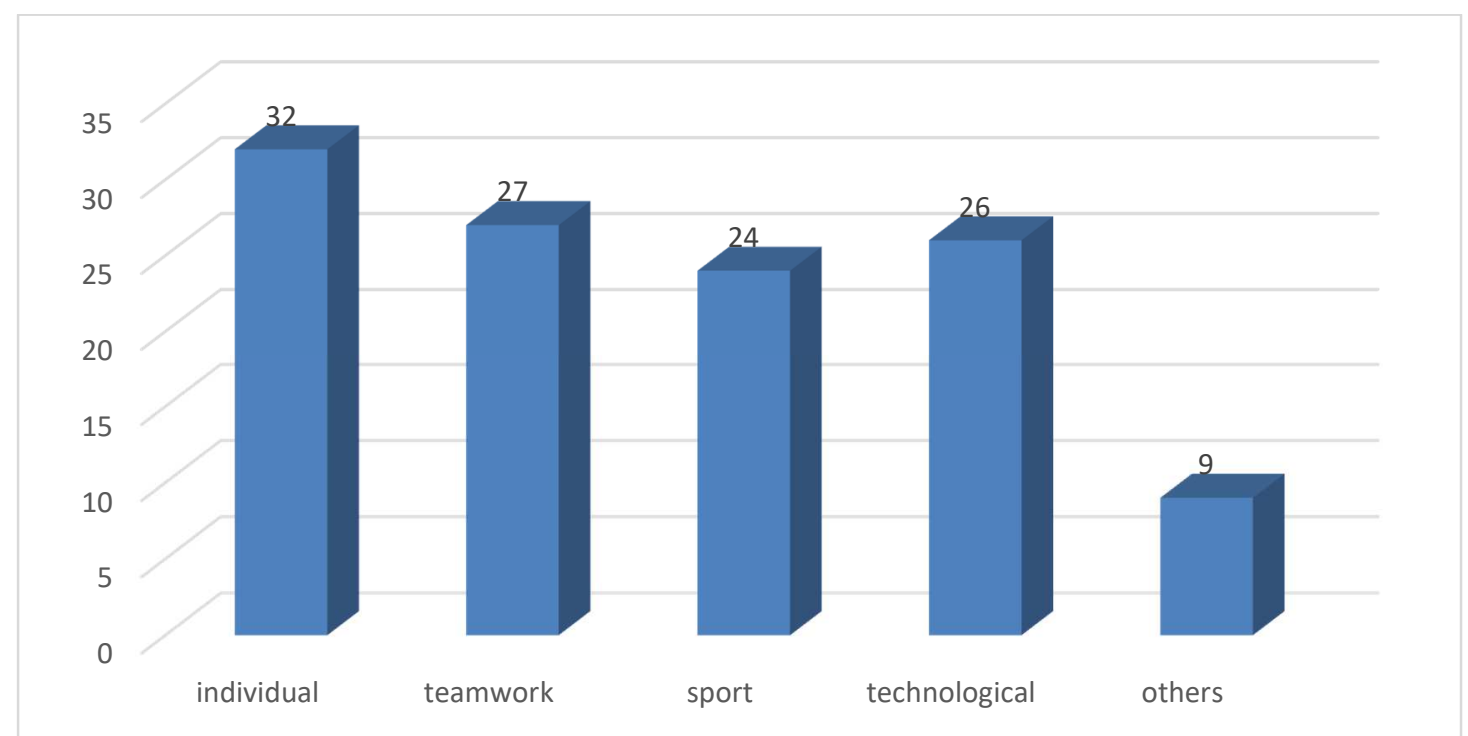

Figure 6 Total answers for question about field of creative feature respondents posses

Most respondents had hobbies related to technology, arts and sports. Among others mentioned were the following hobbies: photo taking, knowledge about animals, Fire Prevention, "great imagination", "artistic", "no abilities".

As one can see in the chart, respondents have a similar extent of technical and artistic, as well as active like sport. A smaller group are musically lover. One person believes that he has no abilities, and one has defined his abilities as "artistic". Other people who chose the option "other" indicated abilities listed in the survey and the addition hobbies mentioned above.

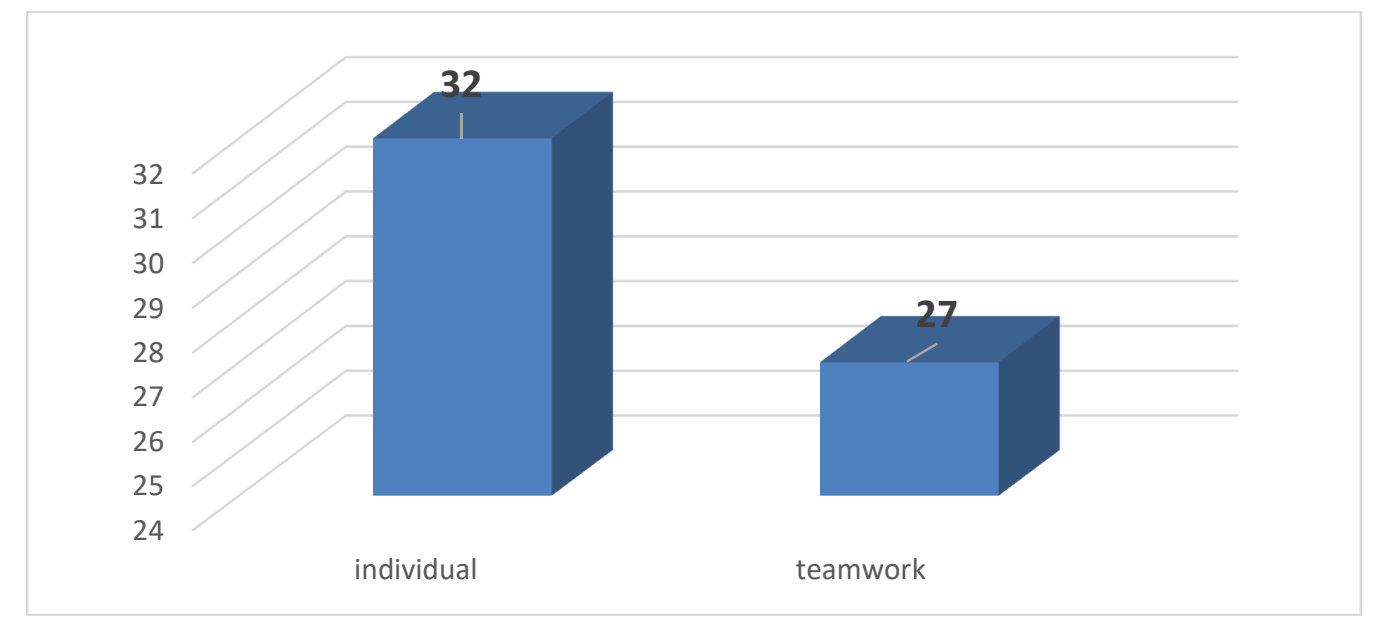

Figure 7 Total answers for question "What do you prefer use while performing a task requiring to be creative" 
Division into individual work and teamwork had a indirectly showed what type of operation the respondents prefer. As the chart shows, in general, these values are very similar. In contrast, majority of respondents of junior high school students will want to work in a team $(60 \%)$ than the individual $(40 \%)$. In secondary school, these proportions were similar - with a slight predominance of individual work $(52.5 \%)$ over team $(47.5 \%)$. The surveyed adults prefer individual work $(71 \%)$ than in a team $(29 \%)$. Nowadays, the ability to work in a team is important for employers because wile different tasks, often described as the team projects requires cooperation with them of a number of people (depending on the task). These people must be able to communicate with each other, solve problems and conflicts, to share their knowledge at the appropriate level. Based on respondents' answers you can draw the following conclusion must be allowed more young people to work in small teams to learn to cooperate in solving specific tasks.

Another question concerned the cooperation in the group, and especially its effects in relation to the implementation of creative tasks. I wrote it in the questionnaire because I wanted to figure out how according to respondents teamwork affects the implementation of creative tasks. To help answer - in the question I put the statement "better results" being reference to giving proper answers. The question was associated with the previous task because it is formulated in such a manner. Another research question was: In your opinion, does cooperation within the group helps you get better results when performing such tasks?

Table 2 Opinions about cooperation within the group when performing creative tasks?

\begin{tabular}{|c|l|l|l|}
\hline & \multicolumn{3}{|c|}{ Number of answers } \\
\cline { 2 - 4 } & \multicolumn{1}{|c|}{ Yes } & \multicolumn{1}{c|}{ No } & Hard to say \\
\hline $\begin{array}{c}\text { Gymnasium } \\
\text { students }\end{array}$ & 71 & 21 & 19 \\
\hline $\begin{array}{c}\text { Secondary schools } \\
\text { studets }\end{array}$ & 67,5 & 12,5 & 20 \\
\hline Adults & 57 & 19 & 14 \\
\hline
\end{tabular}

In all groups, you will see that the respondents consider working in teams to be more effective, while having the choice of artistic task rather perform individually or in groups, they would prefer to work individually. Therefore, the proposal to try to prepare such tasks, exercises and projects that students could work together and see the positive effects of such cooperation, not only of achieving objectives but above all contacts between the human beings and the integration of students 


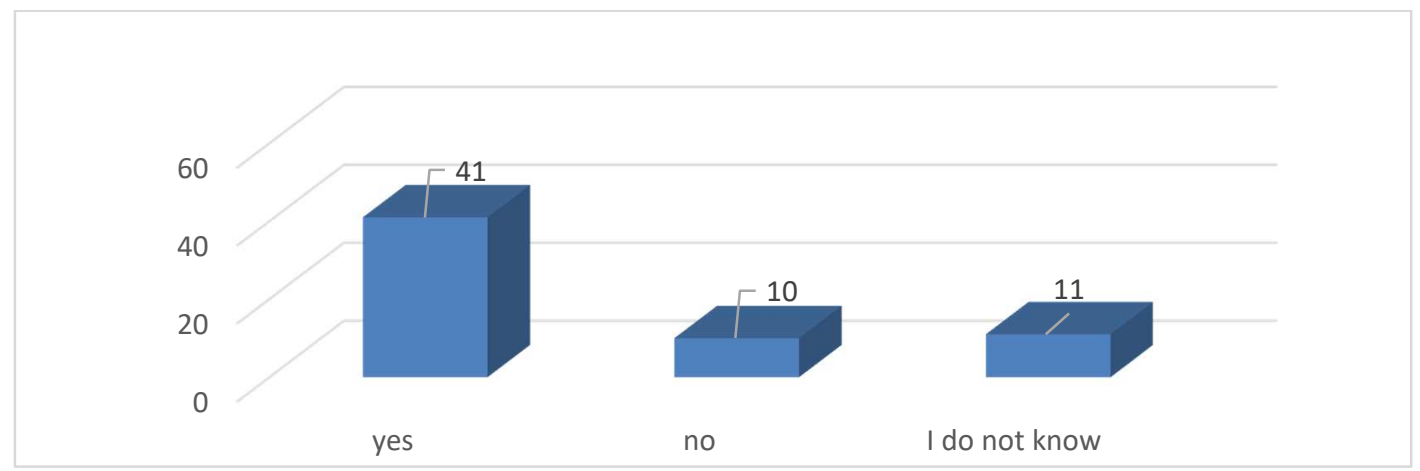

Figure 8 Declaration for preferred team or individual work

Analyzing the overall results of all respondents, it can be observed that the respondents recognize the superiority of teamwork in order to achieve better results. I think that this is connected with the fact that more people share their knowledge and experience and it is easier for them to achieve goals.

Later in the study we asked How to motivate students for creative activity and who do you think should most encourage students to develop creative skills.

Table 3 Opinions persons that should encourage students to develop their creative skills?

\begin{tabular}{|c|l|l|l|l|}
\hline \multirow{2}{*}{} & \multicolumn{4}{|c|}{ Number of answers } \\
\cline { 2 - 5 } & $\begin{array}{c}\text { Parents } \\
\text { family }\end{array}$ & Teachers & $\begin{array}{c}\text { Friend and } \\
\text { school mates }\end{array}$ & other \\
\hline Gymnasium students & 57 & 50 & 14 & 21 \\
\hline Secondary schools studets & 65 & 20 & 10 & 12,5 \\
\hline Adults & 71 & 29 & 0 & 0 \\
\hline
\end{tabular}

Data presented in the table is show that, people from this age group most expect support from their parents and families, which is obvious, but unfortunately, not necessarily for both sides - the parent is not always convinced of the importance of his opinion in a relationship with a young man. Students from the junior high school, argue that the support of teachers is also important to them. So every teacher should support the creative skills of students.

Below is a graph featuring collective data of all respondents. 


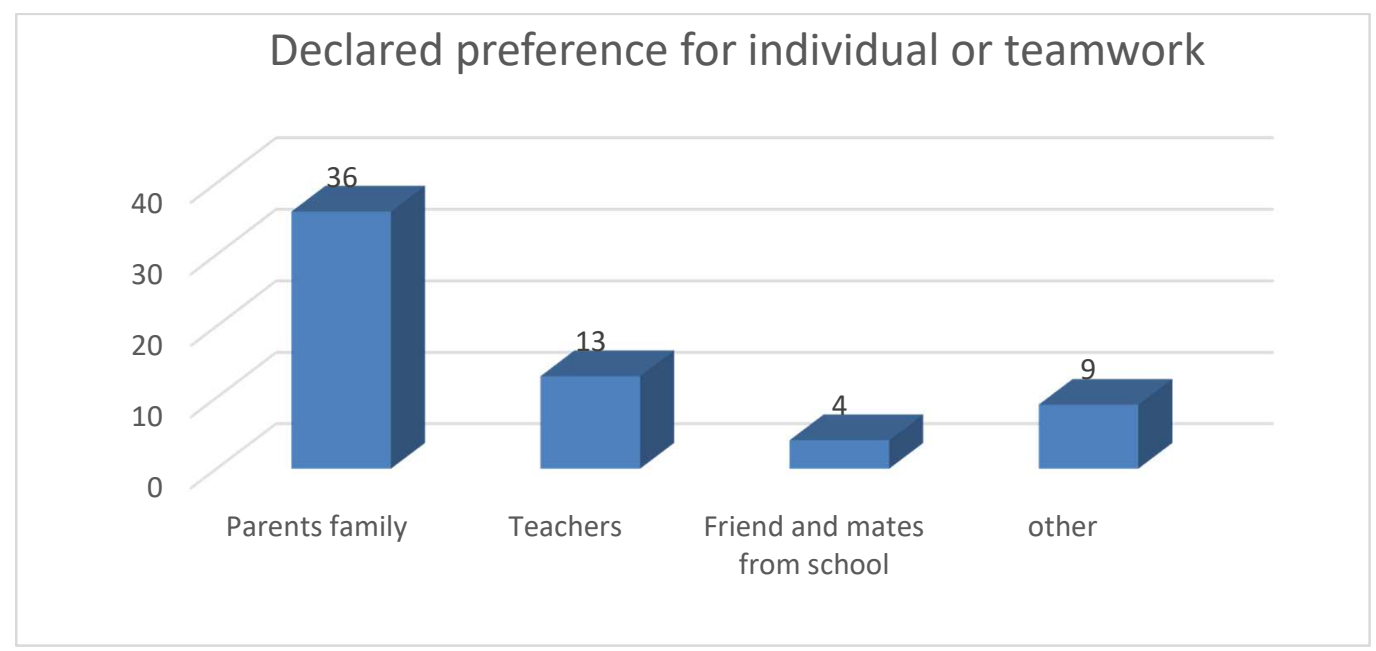

Figure 9 Opinions about source of inspire for creative work

The graph shows the significant impact that should have parents, and how important is their support for all examined groups. there were answers provided also as different in the "other", they were as follows: own ambition, myself and the mix of people, which should support them ie. As the question was single choice you can select one answer. motivating factors are received prizes, praise by parents and family, and obtaining high grades. Differences between the further answers are small. (Tureková i in., 2014) (Sobczyk et al., 2015)

According to the respondents people who should support students in developing their creative skills are the parents and it is they who need to praise their children for any progress and work made by them. Parents and family are some of the main factors motivating the student to work. In the context of the study may be noted major action motivating factor being the value of material reward, which is very little but still "defeated" by parents approbation. Especially I observe this phenomenon among young people of secondary school. Knowledge is not so important as benefit but what they will receive in return for the performance of a specific task - especially material factor. Based on received responses in this question one can draw another conclusion - much appreciated are praise of other people, polite, kind words addressed to others, which are recognized in a positive opinion on the implementation of the task. This confirms my thoughts on pupil motivation. Praised student is more willing to act, perform better and is creative in the classroom, trying to listen and learn after giving the correct answer to be commendatory. 


\section{Conclusions}

Through these research one can specified what classes - workshops are students interested in, at different stages of education, especially in secondary school, they get to know the factors, which are motivation for research in the techniques that already know, was discovered their opinions on topics related to the work or working as individual or teamwork.

On the basis of research factors that create creativity are: knowledge, abilities and skills, the ability to develop their own individual interests, level of motivation.

Creativity is present in life of every human, from an early age, through the various stages of education, adulthood and at older age. Creative people have more passion and willingness to act, have a better motivation set to committed clear goals and strive to achieve them creativity develop, cause that the world around us becomes more friendly, through various products facilitate everyday life. I also met their associations with the word "creativity" through additional question - included in the questionnaire. And with these associations I would like to end my reflections on the creativity at different stages of education.

\section{References}

Depešová, J., \& Tomková, V. (2001). Tradičné technológie a 21. storočie. In:. Zborník Premeny Slovenského školstva na prahu nového milénia. p. 410 - 413. Nitra: PF UKF.

Góralski, A. (1990). Być nowatorem. Poradnik twórczego myślenia. Wyd. PWN, Warszawa,

Gumuła, S., Pytel, K., \& Piaskowska-Silarska, M. (2014). Environmental and economic benefits of using the kinetic energy of wind to generate electricity. Polish Journal of Environmental Studies, No 1.

Gumuła, S., Pytel, K., \& Piaskowska-Silarska, M. (2014). Polemical remarks to the claim that carbon dioxide strengthens greenhouse effect in the atmosphere. Polish Journal of Environmental Studies, No 1.

Haskova, A., Turekova, I., \& Depesova, J. (2015). Quality Training of Future Professionals in Occupational Safety and Health Conference: 6th LUMEN International Conference on Rethinking Social Action Core Values Location: Iasi, Date: APR 16-19, Sponsor(s): LUMEN.RETHINKING SOCIAL ACTION. CORE VALUES p. 645-650. Romania.

Kołodziejski, M. (2009). Twórczość codzienna w praktyce edukacyjnej, Wydawnictwo PRINTPAP, Płock

Kubicka D. ( 2005). Strategie i techniki badania twórczości, w: Poszukiwanie zastosowań w psychologii twórczości red. A. Tokarz, wyd. UJ, Kraków.

Prauzner, T., \& Ptak, P. (2014). Analiza parametrów pracy wybranych czujników pola magnetycznego. Przeglad Elektrotechniczny, nr 12/2014, p. 273-276.

Ptak, P., \& Prauzner, T. (2013). Badania czujników detekcji zagrożeń w systemach alarmowych. Przeglad Elektrotechniczny, nr 10/2013, p. 274-276.

Pytel, K., Jaracz, K., \& Gumuła, S. (2012). An impact of chosen construction parameter and operating conditions on the quality of wind turbine energy generation. $13^{\text {th }}$ International Carpathian Control Conference (ICCC). p. 592-595. Rzeszów. 
Henryk Noga, Barbara Garbarz-Glos, Krzysztof Pytel, Piotr Migo. Conditions of Technical Creativity at Various Stages of Education

Pytel, K., \& Jaracz, K. (2012). Analiza możliwości wykorzystania wybranych hybrydowych układów pozyskiwania energii ze źródeł odnawialnych. Przegląd Elektrotechniczny, $n r$ 9/2012, p. 243-249.

Pytel, K., Jaracz, K., \& Gumuła, S. (2012). An impact of chosen construction parameter and operating conditions on the quality of wind turbine energy generation. $13^{\text {th }}$ International Carpathian Control Conference (ICCC), p. 592-595. Rzeszów.

Sobczyk, W., Sternik, K., Sobczyk, E. J., \& Noga, H. (2015). Ocena plonowania wierzby nowożytnej osadami ściekowymi, Annual Set The Environment Protection. Volume 17. 1113-1123.

Szmidt, K. J. (2007). Pedagogika twórczości, wyd. GWP, Gdańsk

Tureková, I., Depešová, J., \& Bagalová, T. (2014). Machinery risk analysis application in the system of employee training, Applied Mechanics and Materials, Volume 635-637, Pages 439-442, 4th International Conference on Advanced Design and Manufacturing Engineering, ADME 2014; 26 July 2014 through 27 July 2014 Hangzhou, China. 